\title{
FEMALE'S LEADERSHIP ON MARINE BOARD
}

\author{
Rini Setiawati ${ }^{1}, H_{0 o n y}$ Fiva Akira ${ }^{2}$,Erni Pratiwi Perwitasari ${ }^{3}$ \\ 1. STMT Trisakti, 2. STMT Trisakti, 3. STMT Trisakti \\ $\triangle$ corresponding author: rinikimi@yahoo.com
}

\begin{abstract}
The phenomenon of feminism becomes an interesting topic to be discussed, especially for jobs that still dominated by men, the object of this study is the female captain, how they can do double role as wife, mother, and leader on a ship and what kind of leadership style whether applied on board in order to achieve maximum performance that compete to the male captain. The research method used is qualitative research method because there is a problem or issue that need to be explored. The approach used in this research is Phenomenology approach. Phenomenology studies describe the general meaning of some individuals to their various life experiences related to concepts or phenomena. The results are the significant difference between the male and female leadership style of marine captain is that the female captain usually uses rational and logic as well as with sense and tolerance, participatory leadership and transformation are more often used andusual barriers are scepticism of competence and skill and unequivocal impacts of gender stereotypes. This can be anticipated by the superiority of feminism theory to embrace subordinates.
\end{abstract}

Keywords: Phenomenology; leadership styles; participatory; transformation; stereotypes; feminism theory.

\section{Introduction}

Seafarer's world is always identical belong to men. It is natural, because the duration and rigors of life aboard ships for several months, natural threats such as storms or high waves instantly, living conditions that must be separated away from families that also have many risks. Currently, some female are already become a captain, although the captains have been dominating by men. Female's leadership in the maritime is a hot issue, other thing that scarcity of female that being the captain and these great female should be able to take over the commando under all the crew. Many doubted the capabilities and roles of female aboard the ship as a captain, but those female on board could cripple the growing issues among the public. No one thought, there are really great female who recorded in history as a tough captain.

The phenomenon of feminism becomes an interesting topic to be discussed, especially for jobs that still dominated by men, the object of this study is the 
female captain, how they can do double role as wife, mother, and leader (captain) on a ship and what kind of leadership style whether applied on board in order to achieve maximum performance that compete to the male captain.

Equipped with knowledge, expertise and standard competences, female are able to compete with men in the maritime field. Both physically and mentally, female are not inferior to men. Some differences in leadership style of the man or woman captain is the man captain more rational in thinking and logic while the woman captain beside using rational and logic also use a sense and better understand to the crew condition that working under pressure. However, in terms of profession responsibility, both man and female captains must be firm.Focus of this research is the profession of female captain in Indonesia with sub-focus includes the leadership style of a female captain and the factors that influence the success of team work on marine board with female leadership.

Based on the background that has been submitted then the problem formulation of this research is (1) Is there any difference of leadership style between woman captain with men captain, (2) What leadership style usually used by sailor female in doing the task and responsibility as captain, (3) What are the constraints that often arise in running a job as a captain and how to solve it.

Research Benefits , (1) Provides an overview of female's captain lives in the roles and responsibilities of leaders on marine board including the captain characteristics that needed in order to achieve maximum team performance, and (2) Provide input to shipping companies and crewing agencies in the process of recruitment and selection for female crew and captain.

\section{Literature Review}

Leadership on Marine Board

A good leader will play a leadership role by making intellectuals his tool and morale as his master, so intellectuals must be able to serve morals. In fact, Einstein centuries ago had argued that human beings should be careful not to 
deify intellectuals although intellectuals possess tremendous power, but intellectuals have no personality. Intellectuals can not lead because intellectuals can only serve. Leadership is a person's ability to influence himself or others, so leadership is the inherent potential of human identity. (Tasmara, 2009)

The leadership model that goes on board is a team leadership model. A team is a special kind of group whose members are interdependent, have common goals, and must coordinate their activities to achieve that goal. The team has a special role for its members with the knowledge and skills necessary to carry out its role.(Levi D, 2011).Effective team performance begins in a leader's mental model that is resistant to various situations. The mental model reflects not only the problem components of the team but also the environmental and organizational conditions. The leader develops a model of what the team's problem is, what situations might be based on environmental and organizational barriers and resources. (Zaccaro, SJ, 2012) Characteristics of team strength (1) Clear and inspirational goals, (2) Outcome-focused structure, (3) Qualified team members, (4), Commitment, (5) Collaborative climate, (6) 7) Support and acknowledgment of external parties and (8) Ethical leadership. Ethical leadership is a leader who is loyal to team goals and gives members autonomy to use their abilities whenever possible.(Northouse, 2016).

Many responsibilities of leadership on board, i.e (1) to increasing and maintain the discipline. The discipline has a strong relationship with work productivity. Second, compensation has a strong relationship with work productivity. Third, discipline and motivation jointly strong associated with work productivity. (Honny Fiva Akira Sembiring, 2016). (2) to ensure competency of crew , Human error which cause ship accidents is generally related to the competence of the crew to operate the ship. Problems that often occur include an inadequate number of personnel, expertise, and skills of the crew not in accordance with the type and size of vessel. Additionally, there is also incompetence of skipper, navigator and engineer in navigation, 
cargo handling, operating machinery, equipment and ships, as well as negligence in performing other tasks. (Wiweko \& Edi, n.d.)

Leadership Styles

The style of leadership is very important because the style of leadership reflects what the leader does in influencing his followers to realize his vision. The style of leadership is the way leaders influence their followers, in the application of a leadership style influenced by culture. The style of leadership is the followers' perception of the leader's behavioral patterns when trying to influence his followers. (Luthan, 2002).Wirawan defines leadership style as a leader's behavior pattern in influencing attitude, behavior, attitude and so on from his followers. The notion of behavioral patterns is not in a static sense but in a dynamic sense. The leadership style of a leader can vary depending on the quantity and quality of followers, the situation and culture of the social system. A leader can use a number of different patterns of behavior or style in influencing his followers.(Wirawan, 2013)

Hodgetts in(Yasin, 2013), leader behavior will be divided into three leadership styles namely (1) Authoritarian leadership: Centralized work behavior to complete the work. focus based on work progress, work procedures, preventable obstacles to achieving goals. leaders will use this style of leadership in accordance with the circumstances and situations that occur even though this leadership style is considered the most effective in overcoming the crisis, (2) Paternalistic leadership: Centralized working behavior along with the leader's attention to his employees. Leaders instruct employees to work hard but on the other hand employees will be promised some benefits from companies such as health insurance and pension programs, (3) Participative leadership: a combination of work, duties and employees centrally to organize staff.

Empowerment of members is a thing to do from a leader by looking at the ability of its members. The more members are able and courage to solve the problem more independently, the more effective the leader can run the organization. (Pahala, 2016). 
The following research results related to the leadership of a woman: Differences in leadership behavior by gender, in that women exhibited more enabling behavior, and men more challenging behavior. Further, gender and personality had an impact on leadership behavior, as viewed by both leaders and subordinates. For example, extraverted and intuitive male leaders along with those exhibiting the perceiving dimension regarded themselves as more challenging than their introverted, sensing and judging male counterparts, a view confirmed by subordinates in the case of perceiving male leaders. (Brandt \& Laiho, 2007). The study also shows that in terms of abilities in all the areas reviewed, women are able to attain management positions and can perform creditably in school management. Therefore, equal opportunities should be given to both sexes in order to tap their talents and abilities for societal progress. (Eugenia, 2000)

\section{Method}

The research method used is qualitative research method because there is a problem or issue that need to be explored. This exploration is implemented because of the need to study a particular group or population, identifying variables that are not easy to measured. The need for a detailed understanding of a problem as well as a desire to empower individuals to be able to tell their story.(Creswell, 2007)In this case researchers want to explore the life of marine captain, especially the woman ship's captain and identify the leadership character.

There are 5 approaches in Cresswell's qualitative methods: (1) Narrative Research, (2) Phenomenology, (3) Grounded Theory, (4) Ethnography and (5) Case studies, each having characteristics in terms of focus, type of problem the most suitable, the background and the unit of analysis. The approach used in this research is Phenomenology approach. Phenomenology studies describe the general meaning of some individuals to their various life experiences related to concepts or phenomena. 
The main concept in phenomenology is meaning. Meaning is an important content that arises from the experience of human consciousness. To identify the essential qualities of the experience of consciousness in depth and thoroughness.(Smith, 2009). The sample of this study is female marine captain that operating on oil tankers.

\section{Discussion and Result}

\section{Results}

Almost $95 \%$ of the crew are male and generally female crew members are on only Tanker or General Cargo ships. The selection of vessels is usually related to the travel time of the ship, the crew of female tend to choose only short routes. For the position of the shipmaster remains dominated by men because of the lack of female who choose the profession as the Master, but many who have occupied as officers under the Master as Chief Officer, Second Officer, or Third Officer.

The first question asked by a researcher to a captain is "Are you happy with this job?", the answer is there are happines and sorrows while doing the job as a captain of a ship. A pleasure in itself if we can built a solid team, because the crew is a family on board. Intensity meets with crews is more than own family. With a solid team will eliminate the sorrows because of seperated from family and relatives.

In general, the selection of the profession as a captain because of the welfare factor and also because it is the dream. Wages as seafarers are relatively higher compared to landed jobs. In addition, world travel experience is also the reason why choose this profession.

The barriers commonly faced by woman captain are a) Her ability is doubtful by colleagues even by his subordinates, a simple example: The duty of the night shift is considered incapable for a night when over midnight. For this there should be no doubt because all seafarers without regard to gender are treated equally at the time of education of seafarers. b) Considered not assertive because it tends to use feelings in decision making. The life on the ship is often a commotion, in addition to personal factors can 
also be due to structural factors between the work of each other overlap due to lack of compliance from the crew of the ship, For that a leader or captain must have a leadership that can bring the reluctance of the crew.

The significant difference between the male and female leadership style of marine captain is that the male is more thoughtful and acts rationally and logically while the female captain usually uses rational and logic as well as with sense and tolerance, as well as a better understanding of the state of the crew working under pressure. But in terms of responsibility as the Master, both male and female captains should firm.Openness becomes the main point in life on the vessel, especially about the rights of subordinates, the leadership style is not dictatorial or bureaucratic although the skipper must be dominant.

\section{Discussion}

The welfare of a captain by looking at the wages earned is indeed different from the workers on the ground. Sailing wages are relatively higher, in addition to basic salary usually they still receive meal allowance, incentives and others. But not all seafarers are prosperous because the wage system of Domestic Shipping is not the same, some only apply the "all in" wage system, meaning the company only pays wages without any additional even some shipping company still withholds the incentives wage that should be the right of the seafarer in accordance with the Sea Work Agreement between the seafarer and ship's owner.

Frequently question about female's leadership is whether there is a difference between female leadership and male leadership. The differences are based on the following five assumptions: 1) Physical differences, 2) Different types and amounts of hormones. Kenneth's research (2009) suggests that one of the female hormone oxytocin is a factor in how female react to different stress in leadership, 3) the brain. Men process things better in the left brain while the second woman has the same brain processing ability. This difference explains why men are stronger in their left brain activity and problem-solving approach while female solve problems more 
creatively and more aware of feelings when communicating. 4) Psychology, the difference in psychology affects the differences in the mindset, attitudes and behavior of female toward the behavior of men. 5) Perception of the social environment, Society has different perceptions of female, first because of the culture that has developed and formed in a long time. In a growing culture, female can only act as leaders at home.(Achua, Christopher, 2010)

There are 7 Leadership characters on aboard ships : a) Deity to God Almighty, Sea which is a very appropriate place to reflect on self, when on land the sailor feels to be a strong and strong man but when in the sea, sailor is only a creature weak and helpless.. This is the earliest foundation for the seafarers' leadership, b) Never thought about sinking a ship. Ships and the sea are one unity. Everyone on board will never attempt to leak the ship because all want to be safe, c) Democracy is implemented before the ship departs, before the ship departs all may discuss and convey opinions but when the vessel has been decided to the road then there is no more democracy. Leadership aboard the ship absolutely belongs to the ship's captain as the person responsible for all activities and events on board, d) The captain is fully responsible, should be ready to sacrifice himself because a captain is responsible not only for the crew but also responsible to the family of the crew, e) The captain should have a clear purpose, meaning should be determinant of the destination of the ship and how to reach the place. To avoid the ship ran aground. f) Sea tolerance, the habit of doing at sea when meeting other vessels is mutually reciprocal greetings, this is to ensure that the ship does not collide with each other and also help each other fellow ships. So tolerance should be done not only on board but also fellow ships. Aboard the ship is not taught individualism but instilled a sense of togetherness, g) Balance stability, if on board the vessel must pay attention to the balance of the vessel is taught to maintain the stability of the ship with the arrangement of the laying of something on board must be in accordance with the capacity of the ship. 
During the 20th century, discrimination on the basis of sex was supported by the old belief that men were more qualified than female for leadership roles. This belief involves assumptions about the traits and skills required for effective leadership in the organization (implicit theory), assumptions about inherent differences between men and female (gender stereotypes), and assumptions about appropriate behavior for men and female (role expectations). Implicit theories and stereotypes are also influenced by cultural values for gender equality. There is no empirical support for the belief that men are more qualified to be leaders. (Yukl, 2015)

The theory of the superiority of feminism breaks the theories above and there is even a statement saying that female are more likely to have the values and skills necessary for effective leadership in an organization. Feminine values such as kindness, sympathy, parenting and attitudes to sharing cause female to be more concerned with building consensus, participation and interpersonal relationships. Female are more willing to develop and maintain subordinates and share power with them. Female are believed to have more empathy, more to rely on intuition and be sensitive to the feelings and quality of relationships.

\section{Conclusion}

- The significant difference between the male and female leadership style of marine captain is that the male is more thoughtful and acts rationally and logically while the female captain usually uses rational and logic as well as with sense and tolerance.

- Participatory leadership and transformation are more often used by female captain than male. The main difference is the behavior of the female captain who supports the skills and development of his subordinates,

- The usual barriers are skepticism of competence and skill and unequivocal impacts of gender stereotypes. This can be anticipated by the superiority of feminism theory to embrace subordinates. 


\section{References}

Achua, Christopher, R. N. L. (2010). Effective Leadership. Canada: South-Western Cengage Learning.

Brandt, T., \& Laiho, M. (2007). Gender and personality in transformational leadership context An examination of leader and subordinate perspectives. https://doi.org/10.1108/01437731311289965

Creswell, J. (2007). Qualitative Inquiry and Research Design - Choosing among Five Traditions. United Kingdom: Sage Publication.

Eugenia, N. (2000). School Management Positions and Women Empowerment - A Rwandan Case, 180-187.

Honny Fiva Akira Sembiring, D. W. E. (2016). KESEIMBANGAN ANTARA DISIPLIN KERJA DAN KOMPENSASI DENGAN PRODUKTIVITAS KERJA KARYAWAN DI PERUSAHAAN PELAYARAN. Jurnal Manajemen Transportasi Dan Logistik, STMT, 2(3).

Levi D. (2011). Group dynamics for teams. Thousand Oaks, CA: Sage Publication.

Luthan, F. (2002). Organizational Behaviour. New York: MC Graw Hill Higher Education.

Northouse, P. G. (2016). Leadership: theory and practice. Leadership: theory and practice (6th editio). Thousand Oaks, CA: Sage Publisher.

Pahala, Y. K. M. (2016). Employees Empowerment and Service Quality, 3(3), $339-348$.

Smith, A. (2009). Psikologi Kualitatif. Yogjakarta: PT. Pustaka Pelajar.

Tasmara, T. (2009). Spiritual Centered Leadership. Kepemimpinan Berbasis Spiritual. Jakarta: Gema Insani Publisher.

Wirawan. (2013). Kepemimpinan-Teori, Psikologi, Perilaku Organisasi, Aplikasi dan Penelitian. Jakarta: PT. Rajagrafindo Persada.

Wiweko, A., \& Edi, D. W. (n.d.). The Effect of Vessel Seaworthiness and Crew' s Competence on Marine Safety, 2(3), 287-296.

Yasin, M. (2013). Membangun Organisasi Berbudaya - Studi BUMN. Jakarta: Expose.

Yukl, G. (2015). Leadership in Organizations (7th Editio). New Jersey: Pearson Education, Inc.

Zaccaro, SJ, R. A. . \& M. (2012). Team Leadership. Leadership Quaterly, 12, 451452. 